\title{
Effects of Temperature and Light on Growth Rate and Photosynthetic Characteristics of Sargassum horneri
}

\author{
WANG Yong ${ }^{1), 2)}$, ZHONG Zhihai ${ }^{2)}$, QIN Song ${ }^{2)}$, LI Jialin ${ }^{2)}$, LI Jinging ${ }^{1), ~ *, ~ a n d ~ L I U ~ Z h e n g y i ~}{ }^{2), *}$ \\ 1) Key Laboratory of Marine Hazards Forecasting, Ministry of Natural Resources, Hohai University, Nanjing 210098, China \\ 2) Yantai Institute of Coastal Zone Research, Chinese Academy of Sciences, Yantai 264003, China
}

(Received February 25, 2020; revised October 27, 2020; accepted November 3, 2020)

(C) Ocean University of China, Science Press and Springer-Verlag GmbH Germany 2021

\begin{abstract}
The changing environmental factors exerted great influences on coastal macroalgal communities. To study the responses of the brown seaweed Sargassum horneri to temperature and light, S. horneri was cultured under three temperatures $\left(20,25\right.$ and $\left.30^{\circ} \mathrm{C}\right)$ and three light intensities $\left(30,60\right.$, and $120 \mu \mathrm{mol}$ photons $\left.\mathrm{m}^{-2} \mathrm{~s}^{-1}\right)$ for seven days. The growth rate, chlorophyll $a$ (Chl $a$ ) and carotenoids (Car) contents, chlorophyll fluorescence, and photosynthetic oxygen evolution rate were measured. The results show that the highest relative growth rate (RGR), maximal electron transport rate $\left(\mathrm{rETR}_{\max }\right)$; the net photosynthetic rate $\left(P_{\mathrm{n}}\right)$ were observed at the lowest temperature $\left(20^{\circ} \mathrm{C}\right)$ and highest light intensity $\left(120 \mu \mathrm{mol}\right.$ photons $\left.\mathrm{m}^{-2} \mathrm{~s}^{-1}\right)$; and the RGR and $P_{\mathrm{n}}$ were significantly inhibited by the highest temperature $\left(30^{\circ} \mathrm{C}\right)$, especially at the lowest light intensity $\left(30 \mu \mathrm{mol}\right.$ photons $\left.\mathrm{m}^{-2} \mathrm{~s}^{-1}\right)(P<0.05)$. Additionally, the highest light intensity enhanced the non-photochemical quenching $(\mathrm{NPQ})$ even under the highest temperature $\left(30^{\circ} \mathrm{C}\right)$, indicating that the higher light intensity could induce photo-protection reaction of thalli. These results suggest that the higher temperature and lower light intensity exerted negative influences on S. horneri.
\end{abstract}

Key words chlorophyll fluorescence parameter; ocean warming; oxygen electrode; photosynthetic activity; Sargassum horneri; transparency

\section{Introduction}

Global climate change has caused ocean warming $(\mathrm{Ji}$ et al., 2016), which exerts great influences on the marine ecosystem (Diaz-Pulido et al., 2011; Wernberg et al., 2016; Khan et al., 2018). The elevated temperature has exerted a notable impact on the biochemical components of algae and physiological characteristics (Liu et al., 2017). According to Gao et al. (2018a), the chemical composition of algae, such as amino acids, fatty acids and lipid, was increased with culture temperature within a certain range. It also has been proved that temperature determines the performance of seaweeds by influencing enzymatic activities as well as diffusional rate and membrane transport efficiencies (Hoegh and Bruno, 2010; Harley et al., 2012). Moderate increment of temperature would increase light-harvesting pigments content, promote enzyme activity, and accelerate metabolic levels, which could enhance the photosynthesis and growth of algae, but the mortality risk would significantly increase also and local populations might decline or even extinct once the threshold was exceeded (Hoegh and Bruno, 2010; Wu et al., 2019). Furthermore, the elevated temperature

* Corresponding authors. E-mail: lijingjing@hhu.edu.cn has changed the biodiversity and species composition of coastal ecosystems (Olabarria et al., 2013), reshaped the distribution of macroalgae (Müller et al., 2009), and even caused the extinction of several hundred species (Wernberg et al., 2011), which has been reported worldwide (Bartsch et al., 2012). Under the ocean warming scheme, warm water species will intrude into formerly colder regions (Ji et al., 2016), and this trend has been predicted by North-Atlantic rocky intertidal model (Jueterbock et al., 2013). For instance, in the reef system in Australia, kelp forests have extensively shrunk, and temperate species have been replaced by subtropical and tropical ones (Wernberg et al., 2016).

In addition, the eutrophication and the re-suspension of sediments in the coastal zone has reduced the seawater transparency, thus changed the light environment (Zhang et al., 2013; Chen et al., 2014; Rahman et al., 2015). It is known that light is a vital environmental factor for the growth and development of plant, and affects the photosynthetic characteristics through a variety of processes (Su et al., 2014). In general, macroalgae have their own optimal light intensity ranges for growth, sub- and supraoptimal conditions will negatively influent their physiological characteristics (Pan and Guo, 2016; Li et al., 2017). Furthermore, as a signal molecule, light can activate the corresponding regulatory mechanism in the cell, $\mathrm{g}$ exerting /an impact on r thel growth: and development of 
plants (Wang et al., 2009; Gutu et al., 2013). Additionally, light is a determinant for macroalgae depth distribution. A series of studies have reported that algae have their own depth limit, such as planktonic algae, brown kelps, and crustose macroalgae (Hanelt et al., 2003), and the lower depth distribution limit of macroalgae depends on their ability to maintain a positive carbon balance to build up biomass (Deregibus et al., 2016). Large loads of suspended solids may constitute a constraint for benthic primary producer by reducing light penetration, and correlation between increase of turbidity and reduction of the productivity of benthic macroalgae has been established (Eriksson and Johansson, 2005; Pritchard et al., 2013). Studies in Polar Regions reported that the increment of sediment into the water column reduced the light penetration, constituted a constraint for photosynthesis, exerted adverse impact on the growth of benthic algae, and eventually altered the macroalgal communities (Quartino et al., 2013; Deregibus et al., 2016).

Sargassum horneri (Turner) C. Agardh, one of the most common macroalgae, is endemic to the northwestern $\mathrm{Pa}$ cific, and distributes sporadically in coastal regions of China (Zeng et al., 2000). S. horneri is an annual brown macroalgae (Yoshida, 1983), can grow up to 3-5 m long and form a large underwater forest in the ocean, providing habits for a variety of marine invertebrates and fish (Han et al., 2008). Besides, S. horneri can be planted for seaweed bed reconstruction and ecological restoration $(\mathrm{Bi}$ et al., 2013). Furthermore, S. horneri has great economic values, which is a good bait for aquaculture and can provides a variety of biological active compounds for the treatment of a variety of diseases (Ma et al., 2014; Zhao et al., 2016; Sanjeewa et al., 2017). The effects of various culture conditions on growth of $S$. horneri at different stages have been well studied. Compared with adult blades of $S$. horneri, the optimal growth temperature of seedlings was higher (Choi et al., 2008). The optimal light parameters of seedlings were 50-90 $\mu \mathrm{mol}$ photons $\mathrm{m}^{-2} \mathrm{~s}^{-1}$ and long photoperiod (18L:6D) (Zhang et al., 2014). In addition, UV-A could promote its growth under low light conditions (Guan et al., 2016). However, the effects of environmental factors, especially the adverse conditions on the photophysiological response was less discussed.

Many Sargassum forests are in decline in recent decades, and some even have disappeared. The Sargassum forest in Nanji Islands, Zhejiang Province, China, an important national marine ecosystem protection area, has been disappearing. Moreover, the density of Sargassum forest in Gouqi Island, Zhejiang Province, has been decreasing gradually (Sun et al., 2008; Bi et al., 2013). Sargassum forests have also declined markedly and could not be recovered naturally in coastal areas in other Asian countries along the northwestern Pacific (Choi et al., 2008; Komatsu et al., 2014). On the other hand, golden blooms caused by floating Sargassum seem to be in a rising trend (Smetacek and Zigone, 2013; Xu et al., 2017). Komatsu et al. (2014) suggested that the elevated sea (C) $1994-2021$ China Acagemic Journal Electronic Pubir Springer surface temperature might be the cause of northward shift of the southern limit of $S$. horneri kelp distribution. Meanwhile, according to a series of study in Gouqi and Nanji Islands, re-suspension of sediment and eutrophication in coastal waters decreased the underwater light intensity, thus restricted the distribution of $S$. horneri (Bi et al., 2013; Zhang et al., 2013). Based on these studies, we speculate that the decline of Sargasusm forest in these areas may be caused by the combination of high temperature and low light intensity. In this paper, physiological and biochemical response to a combination of light and temperature were studied in indoor culture experiments to understand the interactive influence of the two environmental factors on S. horneri growth, aiming to provide a preliminary theoretical support to the protection and recovery of Sargasusm forest.

\section{Materials and Methods}

\subsection{Materials}

In March 8, 2019, S. horneri was sampled from Gouqi Island $\left(30^{\circ} 42^{\prime} \mathrm{N}, 122^{\circ} 48^{\prime} \mathrm{E}\right)$ in the East China Sea, Zhejiang Province, China. Samples were then transferred to laboratory and cultured in water tanks until the breeding period. S. horneri germlings were collected on April 23 and cultured in tanks at $18^{\circ} \mathrm{C}$, salinity 32 , and light intensity $100 \mu \mathrm{mol}$ photons $\mathrm{m}^{-2} \mathrm{~s}^{-1}$; the medium was sterile natural seawater with addition of $100 \mu \mathrm{mol} \mathrm{L}{ }^{-1} \mathrm{NaNO}_{3}$ and $10 \mu \mathrm{molL}^{-1} \mathrm{KH}_{2} \mathrm{PO}_{4}$, and was renewed once a day. After cultured for 3 months, healthy thalli were chosen for experiment. Prior to the experiment, thalli were cleaned of debris and floc wrapped around algae, then cultured in sterile natural seawater, which was filtered by sand and sterilized by ultraviolet light, enriched by $\mathrm{f} / 2$ medium for $2 \mathrm{~d}$ at $20^{\circ} \mathrm{C}$ under $100 \mu \mathrm{mol}$ photons $\mathrm{m}^{-2} \mathrm{~s}^{-1}$ light condition $(\mathrm{L}: \mathrm{D}=12: 12)$.

\subsection{Treatments}

To detect the effects of combinational temperature and light conditions on $S$. horneri, we set three temperatures $\left(20,25,30^{\circ} \mathrm{C}\right)$ and three light intensities $(30,60,120 \mu \mathrm{mol}$ photons $\mathrm{m}^{-2} \mathrm{~s}^{-1}$ ) with a photoperiod of 12L:12D (triplicate for each treatment) (Table 1). The chosen temperature of $25^{\circ} \mathrm{C}$ was about the ocean temperature during July and August in Changdao, Shandong (Yang et al., 2018), and the lower and higher temperature were the optimal growth and upper threshold temperature of S. horneri. Although the provided light intensity was low, the lowest light intensity was higher than the light compensation point, and highest light intensity is slightly greater than the optimal light intensity (Zhang et al., 2014).

Table 1 The treatment combinations

\begin{tabular}{cccc}
\hline Light & \multicolumn{3}{c}{ Temperature $\left({ }^{\circ} \mathrm{C}\right)$} \\
\cline { 2 - 4 }$\left(\mu\right.$ mol photons $\left.\mathrm{m}^{-2} \mathrm{~s}^{-1}\right)$ & LT $(20)$ & MT $(25)$ & HT \\
\hline LL $(30)$ & LL-LT & LL-MT & LL-HT \\
ML $(60)$ & ML-LT & ML-MT & ML-HT \\
HL $(120)$ & HL-LT & HL-MT & HL-HT \\
\hline hing House. All rights reserved. & http://WWW.cnki.net
\end{tabular}


The $S$. horneri were blotted using filter paper to remove excess water. For each treatment, approximate $0.5 \mathrm{~g}$ was incubated in $500 \mathrm{~mL}$ sterile natural seawater enriched by $\mathrm{f} / 2$ medium. During the light cycle, the medium was stirred with a glass rod every half hour ( $\mathrm{Xu}$ and Lin, 2008). The physiological performance was measured after one week.

\subsection{Growth Rate and Pigments Content Analyses}

The fresh weight was measured every day when renewing the culture medium. The relative growth rate (RGR) was calculated using the following formula: RGR $\left(\% \mathrm{~d}^{-1}\right)=100 \times \ln \left(W_{t} / W_{0}\right) / t$, in which $W_{t}$ and $W_{0}$ represent the fresh weight measured on the $t$ day and the first day.

A fresh weight of $0.03 \pm 0.005 \mathrm{~g}$ of $S$. horneri was used for determining the pigment contents. Samples were ground in methanol $(3 \mathrm{~mL})$ with quartz sand. The homogenate was transferred to a centrifugal tube and placed at $4^{\circ} \mathrm{C}$ for $24 \mathrm{~h}$ in darkness. The chlorophyll $a(\mathrm{Chl} a)$ and carotenoid (Car) concentration were calculated according to Eqs. (1)-(2) (Porra, 2002; Parsons and Stricklan, 1963).

$$
\begin{aligned}
& \text { Chl } a\left(\mu \mathrm{g} \mathrm{mL}^{-1}\right)=16.29 \times\left(A_{665}-A_{750}\right)-8.54 \times\left(A_{652}-A_{750}\right),(1) \\
& \operatorname{Car}\left(\mu \mathrm{g} \mathrm{mL}^{-1}\right)=7.6\left[\left(A_{480}-A_{750}\right)-1.49 \times\left(A_{510}-A_{750}\right)\right] .(2)
\end{aligned}
$$

\subsection{Chlorophyll Fluorescence Parameters}

The induction curves and rapid light curves (RLCs) were built at room temperature in natural seawater using a pulse amplitude modulated fluorometers (Diving-PAM, Germany). The induction curves were established after a 15-min dark adaptation, the $F_{\mathrm{o}}, F_{\mathrm{m}}, F$, and $F_{\mathrm{m}}^{\prime}$ were determined. The actinic light was set as $104 \mu$ mol photons $\mathrm{m}^{-2} \mathrm{~s}^{-1}$ and the saturating pulse was $3577 \mu \mathrm{mol}$ photons $\mathrm{m}^{-2} \mathrm{~s}^{-1}(0.8 \mathrm{~s})$. The parameter $F_{\mathrm{v}} / F_{\mathrm{m}}$ and electron transport rate were calculated by using Eqs. (3)-(4).

$$
\begin{gathered}
F_{\mathrm{v}} / F_{\mathrm{m}}=\frac{F_{\mathrm{m}}-F_{\mathrm{o}}}{F_{\mathrm{m}}}, \\
\mathrm{ETR}=\frac{F_{\mathrm{m}}^{\prime}-F}{F_{\mathrm{m}}^{\prime}} \times \mathrm{PAR} \times 0.84 \times 0.5,
\end{gathered}
$$

where PAR represents the actual light intensity ( $\mu \mathrm{mol}$ photons $\left.\mathrm{m}^{-2} \mathrm{~s}^{-1}\right), 0.5$ is the relative ratio of absorbed PAR to photosystem II, and 0.84 is the ETR-factor representing the fraction of incident photons absorbed by the sample.

RLCs was constructed after the induction curves by exposing to eight increasing level of light. The range of light intensity was from 38 to $1189 \mu$ mol photons $\mathrm{m}^{-2} \mathrm{~s}^{-1}$. The fitting formula of RLCs and calculation of photosynthetic parameters, such as the maximal electron transport rate $\left(\mathrm{rETR}_{\max }\right)$, the half-saturation light intensity $\left(I_{\mathrm{k}}\right)$, the light harvesting efficiency $(\alpha)$ and the Non-chemical quenching (NPQ), were calculated according to Eqs. (5)(8), where $\mathrm{ETR}_{\text {mpot }}$ represents the maximum potential light-saturated electron transport rate, $\beta$ represents the

$$
\begin{gathered}
\mathrm{ETR}=\mathrm{ETR}_{\mathrm{mpot}} \times\left(1-\mathrm{e}^{\frac{\alpha \times \mathrm{PAR}}{\mathrm{ETR}_{\mathrm{mpot}}}}\right) \times \mathrm{e}^{\frac{\beta \times \mathrm{PAR}}{\mathrm{ETR}_{\mathrm{mpot}}},} \\
\mathrm{rETR}_{\text {max }}=\mathrm{ETR}_{\mathrm{mpot}} \times \frac{\alpha}{\alpha+\beta} \times\left(\frac{\beta}{\alpha+\beta}\right)^{\beta / \alpha}, \\
I_{\mathrm{K}}=\frac{\mathrm{ETR}_{\mathrm{m}}}{\alpha}, \\
\mathrm{NPQ}=\frac{F_{\mathrm{m}}-F_{\mathrm{m}}^{\prime}}{F_{\mathrm{m}}^{\prime}} .
\end{gathered}
$$

\subsection{Photosynthetic Oxygen Evolution}

A fresh weight $0.03 \pm 0.005 \mathrm{~g}$ of thalli were weighed and put into a sample beaker containing $2 \mathrm{~mL}$ of natural seawater. The net photosynthetic rate $\left(P_{\mathrm{n}}\right)$ was measured using a Clark-type oxygen electrode (Hansatech Instruments Ltd, UK) at each cultured temperature and light intensity, and the dark respiration rate $\left(R_{\mathrm{d}}\right)$ was measured under dark condition. At least three replicates were evaluated for each treatment.

\subsection{Data Analysis}

Origin 7.0 and SPSS 18.0 were used for plotting and statistical analysis. A two-way ANOVA was used to test the effects of temperature and irradiance on the RGR, pigments content, and photosynthesis. Prior to the data analyses, the homogeneity of variances was verified with Levene's test $(P>0.05)$. A Tukey post hoc test (Tukey HSD) was performed to detect the differences between different temperature and light treatments. $P<0.05$ was considered as statistically significant.

\section{Results}

\subsection{Effect of Light and Temperature on the Growth and Pigments Content}

The two-way ANOVA showed that the temperature and light had significant interactive effects, and both exerted a

Table 2 Two-way analysis of variance for the effects of temperature and light intensity on different parameters

\begin{tabular}{cllcc}
\hline \multirow{2}{*}{ SGR } & \multicolumn{1}{c}{ Source } & F & Sig. \\
\hline \multirow{3}{*}{ Chl $a$} & Temperature & 2 & 21.176 & 0.000 \\
& Light & 2 & 21.667 & 0.000 \\
& Temperature $\times$ Light & 4 & 1.261 & 0.033 \\
& Temperature & 2 & 2.410 & 0.118 \\
Car & Light & 2 & 1.427 & 0.266 \\
& Temperature $\times$ Light & 4 & 2.971 & 0.048 \\
& Temperature & 2 & 0.651 & 0.533 \\
& Light & 2 & 1.904 & 0.178 \\
Chl $a /$ Car & Temperature $\times$ Light & 4 & 2.063 & 0.128 \\
& Temperature & 2 & 2.287 & 0.130 \\
& Light & 2 & 0.349 & 0.710 \\
& Temperature $\times$ Light & 4 & 1.294 & 0.310 \\
\hline
\end{tabular}

Notes: $\mathrm{df}$, degrees of freedom; $\mathrm{F}$, the value of the F statistic. gouse. All rights reserved. http://www.cnki.net 


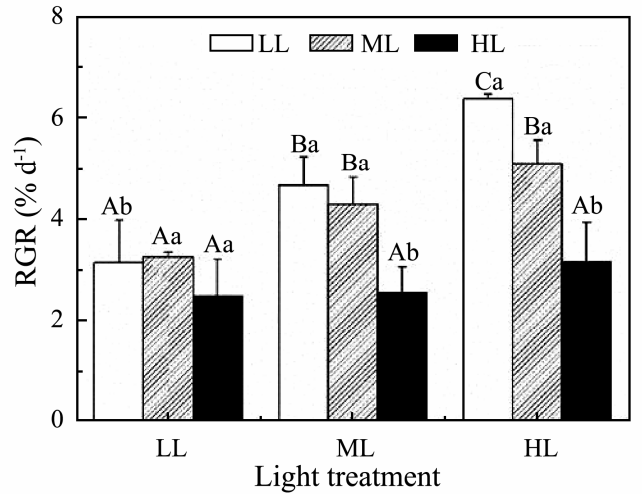

Fig.1 The relative growth rate (RGR) of $S$. horneri grown at different treatment. Values were mean $\pm \mathrm{SD}(n=3)$. Different uppercase letters indicate significant differences between different temperature treatments under the same light intensity; different lowercase letters indicate significant differences between different light treatments under the same temperature $(P<0.05)$.

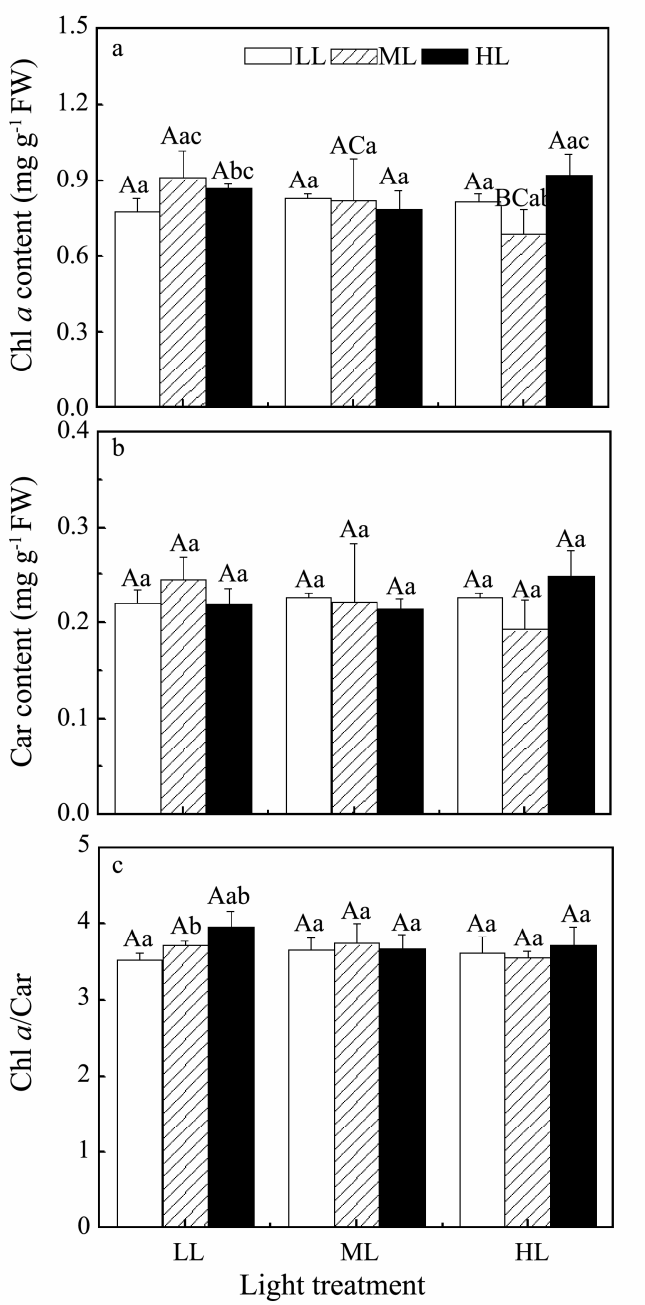

Fig.2 The Chl $a$ (a), Car (b) content, and the ration of Chl $a$ and Car (c) of $S$. horneri grown at different treatments. Values were mean \pm SD $(n=3)$. Different uppercase letters indicate significant differences between different temperature treatments under the same light intensity; different lowercase letters indicate significant differences between different light treatments under the same tempera(ture 6 (P)本-0.955). China Academic Journal Electronic Pub main effect on the relative growth rate (RGR) (Table 2, $P$ $<0.05)$. The RGR of $S$. horneri increased with the increasing light intensity under all the temperatures. Under the low temperature condition $\left(20^{\circ} \mathrm{C}\right)$, the effect of light on the growth rate was significant $(P<0.05)$, the RGR of high light treatments $\left(120 \mu\right.$ molphotons $\left.\mathrm{m}^{-2} \mathrm{~s}^{-1}\right)$ was about 2-fold higher than low light treatments $(30 \mu \mathrm{mol}$ photons $\left.\mathrm{m}^{-2} \mathrm{~s}^{-1}\right)$. However, under the high temperature $\left(30^{\circ} \mathrm{C}\right)$, the difference of RGR between different light was not significant $(P>0.05)$. The highest RGR was observed at high light and low temperature treatments (Figs.1, 2). Besides, these results show that all treatments had the similar contents of Chl $a$ and Car; both temperature and light had no obvious effect on the contents of Chl $a$ and Car (Table 2, $P>0.05)$, and showed no interactive effect on the contents of Car (Table 2, $P>0.05$ ).

\subsection{Effect of Light and Temperature on the Chlorophyll Fluorescence Parameters}

As for $F_{\mathrm{v}} / F_{\mathrm{m}}$ and electron transport rate (ETR) at the end of induction curve, there were no significant differences among all the treatments, and the interactive effects of light and temperature were not significant (Fig.3, Table $4, P>0.05)$. However, the light had a main effect on ETR (Table 3, $P<0.05$ ), the highest ETR occurred at the high light treatment $\left(120 \mu\right.$ mol photons $\left.\mathrm{m}^{-2} \mathrm{~s}^{-1}\right)$.
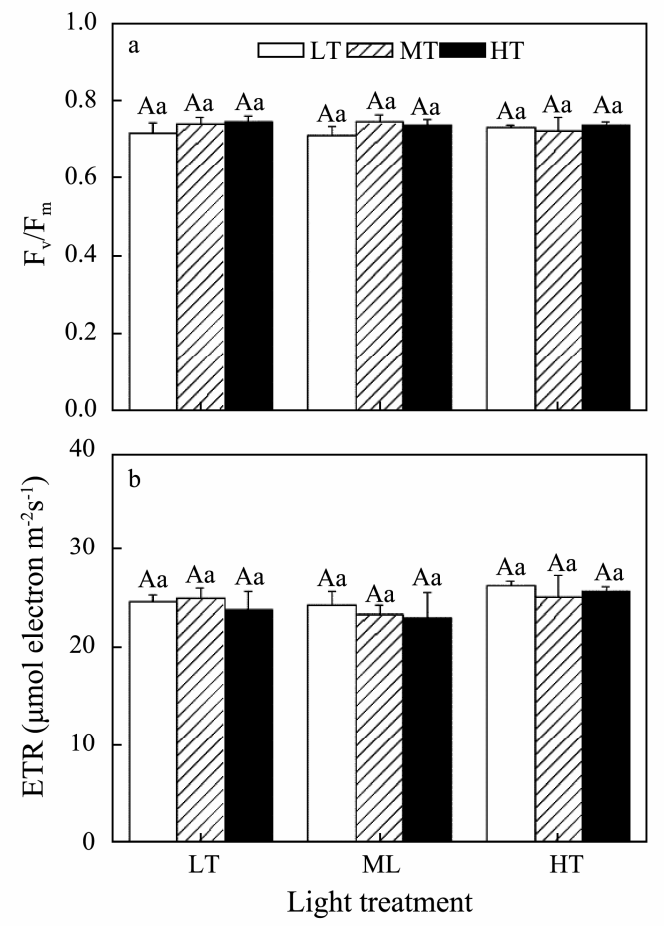

Fig. $3 F_{\mathrm{v}} / F_{\mathrm{m}}$ and ETR of $S$. horneri grown at different treatment. Values were mean $\pm \mathrm{SD}(n=3)$. Different uppercase letters indicate significant differences between different temperature treatments under the same light intensity; different lowercase letters indicate significant differences between different light treatments under the same temperature $(P<0.05)$.

In relation to rapid light curves, the electron transport rate (ETR) of $S$. horneri increased gradually at first and is then Idecreased l aftert reaching the maximumwaluei. With 
Table 3 Two-way analysis of variance for the effects of temperature and light intensity on different parameters

\begin{tabular}{lccc}
\hline \multicolumn{1}{c}{ Source } & df & $\mathrm{F}$ & Sig. \\
\hline$F_{\mathrm{v}} / F_{\mathrm{m}}$ & & & \\
Temperature & 2 & 2.495 & 0.111 \\
Light & 2 & 0.096 & 0.909 \\
Temperature $\times$ Light & 4 & 1.035 & 0.416 \\
ETR & & & \\
Temperature & 2 & 0.895 & 0.426 \\
Light & 2 & 4.528 & 0.026 \\
Temperature $\times$ Light & 4 & 0.334 & 0.851 \\
\hline
\end{tabular}

Notes: $\mathrm{df}$, degrees of freedom; F, the value of the F statistic.

\begin{tabular}{cccc}
\hline Treatment & $\alpha$ & $I_{\mathrm{k}}$ & $\mathrm{rETRmax}$ \\
\hline HL-LT & $0.353 \pm 0.007^{\mathrm{Aa}}$ & $160.029 \pm 17.255^{\mathrm{Aa}}$ & $56.427 \pm 5.063^{\mathrm{Aa}}$ \\
ML-LT & $0.320 \pm 0.022^{\mathrm{Aa}}$ & $168.828 \pm 6.830^{\mathrm{Aa}} \mathrm{b}$ & $53.912 \pm 3.099^{\mathrm{Aa}} \mathrm{c}$ \\
LL-LT & $0.344 \pm 0.017^{\mathrm{Aa}}$ & $134.379 \pm 10.621^{\mathrm{Aa}} \mathrm{c}$ & $46.157 \pm 2.426^{\mathrm{Abc}}$ \\
HL-MT & $0.336 \pm 0.027^{\mathrm{Aa}}$ & $145.855 \pm 17.651^{\mathrm{Aa}}$ & $49.045 \pm 7.341^{\mathrm{Aa}}$ \\
ML-MT & $0.332 \pm 0.020^{\mathrm{Aa}}$ & $126.262 \pm 10.343^{\mathrm{Ba}}$ & $41.824 \pm 3.650^{\mathrm{Aa}}$ \\
LL-MT & $0.361 \pm 0.016^{\mathrm{Aa}}$ & $112.848 \pm 10.753^{\mathrm{ACa}}$ & $40.635 \pm 3.445^{\mathrm{ACa}}$ \\
HL-HT & $0.358 \pm 0.024^{\mathrm{Aa}}$ & $126.871 \pm 28.240^{\mathrm{Aa}}$ & $45.043 \pm 7.297^{\mathrm{Aa}}$ \\
ML-HT & $0.329 \pm 0.023^{\mathrm{Aa}}$ & $121.524 \pm 21.625^{\mathrm{Ba}}$ & $40.381 \pm 9.629^{\mathrm{Aa}}$ \\
LL-HT & $0.352 \pm 0.016^{\mathrm{Aa}}$ & $105.076 \pm 7.528^{\mathrm{BCa}}$ & $36.979 \pm 3.405^{\mathrm{BCa}}$ \\
\hline
\end{tabular}

Notes: Different uppercase letters indicate significant differences between different temperature treatments under the same light intensity; different lowercase letters indicate significant differences between different light treatments under the same temperature $(P<$ $0.05)$.

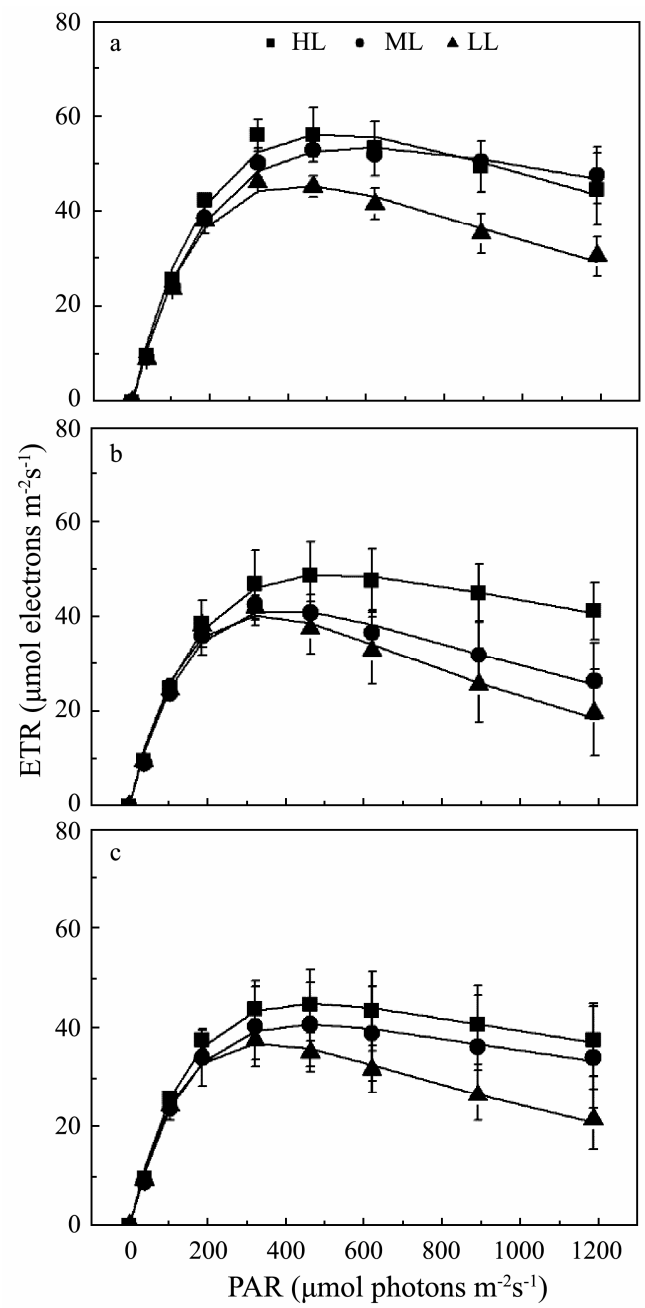

Fig.4 Rapid light curve (P-L curves) of $S$. horneri grown

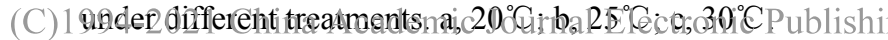

the increasing light. Compared with those at medium$\left(25^{\circ} \mathrm{C}\right)$ and high temperature $\left(30^{\circ} \mathrm{C}\right)$ treatments, the low temperature treatments $\left(20^{\circ} \mathrm{C}\right)$ had higher half-saturation light intensity $\left(I_{\mathrm{k}}\right)$ and maximal electron transport rate $\left(\mathrm{rETR}_{\max }\right) . I_{\mathrm{k}}$ and $\mathrm{rETR}_{\max }$ basically increased with the light intensity under the same temperature, but under the low temperature, $I_{\mathrm{k}}$ at medium light was a little higher than low light although the difference was not obviously $(P>0.05)$. However, the light harvesting efficiency $(\alpha)$ did not change significantly under all the treatments (Fig.4, Table 4, $P>0.05$ ).

Table 4 The photosynthetic parameters of $S$. horneri grown at different treatments 
The non-photochemical quenching (NPQ) increased gradually with the increasing light. The maximum NPQ occurred at high light $\left(120 \mu \mathrm{mol}\right.$ photons $\left.\mathrm{m}^{-2} \mathrm{~s}^{-1}\right)$ treatments, and the medium light $\left(60 \mu \mathrm{mol}\right.$ photons $\left.\mathrm{m}^{-2} \mathrm{~s}^{-1}\right)$ treatments was little higher than that of the low light (30 $\mu$ mol photons $\mathrm{m}^{-2} \mathrm{~s}^{-1}$ ) treatment under all the temperatures. Under high light treatments, the fast and obvious increase of NPQ was observed at each temperature. However, under the medium and low light treatments, the increment of NPQ was smaller with increasing light, and particularly at the high temperature $\left(30^{\circ} \mathrm{C}\right)$ treatments the curves showed barely upward trend (Fig.5).

\subsection{Effect of Light and Temperature on the Photo Synthetic Oxygen Evolution}

The net photosynthetic rate $\left(P_{\mathrm{n}}\right)$ increased significantly with the increasing light at all temperature treatments (Fig. 6a, $P<0.05)$, and the highest $P_{\mathrm{n}}$ occurred at HL-LT (120 $\mu$ mol photons $\left.\mathrm{m}^{-2} \mathrm{~s}^{-1}, 20^{\circ} \mathrm{C}\right) . P_{\mathrm{n}}$ show no obvious difference among different temperature treatments at LL, but
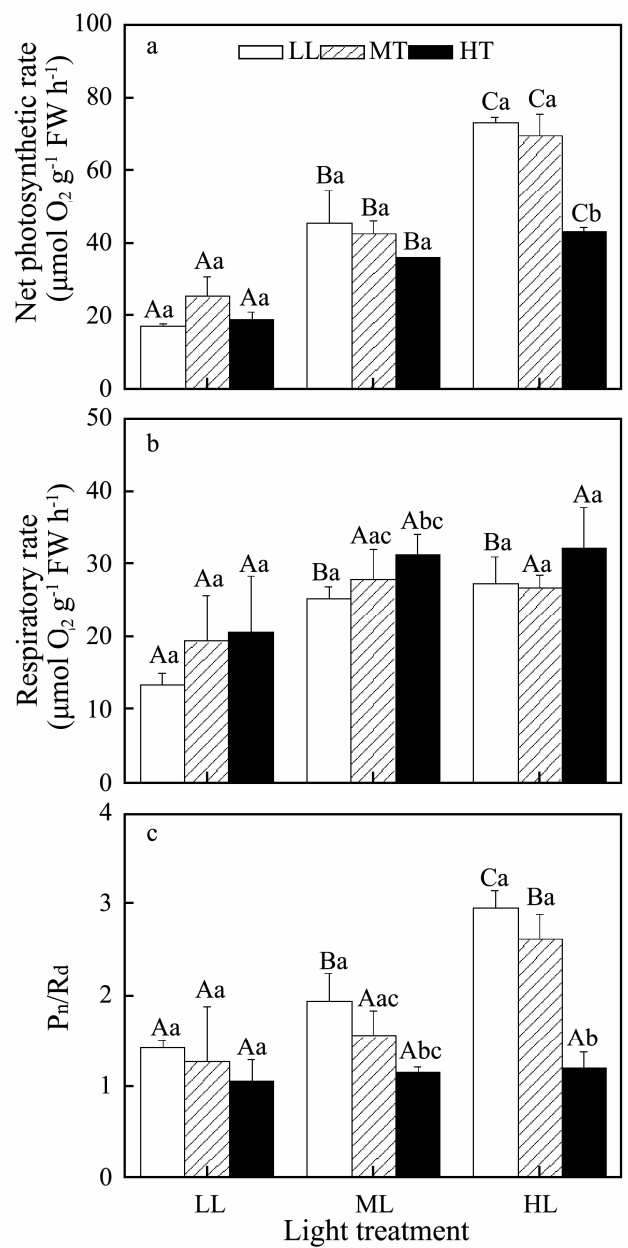

Fig.6 The net photosynthetic rate $\left(P_{\mathrm{n}}\right)(\mathrm{a})$, respiratory rate $\left(R_{\mathrm{d}}\right)(\mathrm{b})$ and $P_{\mathrm{n}} / R_{\mathrm{d}}$ (c) of $S$. horneri grown at different treatment. Values were mean $\pm \mathrm{SD}(n=3)$. Different uppercase letters indicate significant differences between different temperature treatments under the same light intensity; different lowercase letters indicate significant differences between different light treatments under the same temperature $(P<0.05)$. the $P_{\mathrm{n}}$ at HT was significantly lower than those of LT and MT at HL. HL increased $P_{\mathrm{n}}$ to $73.3 \pm 1.37 \mu \mathrm{mol} \mathrm{O}_{2} \mathrm{~g}^{-1} \mathrm{FW}$ $\mathrm{h}^{-1}$ compared to LC's $\left(17.5 \pm 0.47 \mu \mathrm{molO}_{2} \mathrm{~g}^{-1} \mathrm{FWh}^{-1}\right)$ at LT. However, HL only increased $P_{\mathrm{n}}$ to $43.2 \pm 1.15 \mu \mathrm{mol}$ $\mathrm{O}_{2} \mathrm{~g}^{-1} \mathrm{FW} \mathrm{h}^{-1}$ compared to the LC's $\left(19.2 \pm 1.86 \mu \mathrm{mol} \mathrm{O}_{2}\right.$ $\mathrm{g}^{-1} \mathrm{FW}_{0} \mathrm{~h}^{-1}$ ) at HT. Besides, the $P_{\mathrm{n}}$ increased with temperature decreasing. However, under the low light condition, the medium temperature present the highest $P_{\mathrm{n}}$ in all temperature treatments, which is consistent with the RGR, but had no significant difference between them (Fig.6a, $P$ $>0.05)$. With the decrease of temperature and light, the dark respiratory rate $\left(R_{\mathrm{d}}\right)$ decreased; the high temperature $\left(30^{\circ} \mathrm{C}\right)$ and high light treatment showed the maximum $R_{\mathrm{d}}$ (Fig.6b). In addition, the ratio of $P_{\mathrm{n}}$ and $R_{\mathrm{d}}\left(P_{\mathrm{n}} / R_{\mathrm{d}}\right)$ shows a similar pattern to that of $P_{\mathrm{n}}$ (Fig.6c). Results of two-way ANOVA show that temperature and light had significant interactive effects on $P_{\mathrm{n}}$ and $P_{\mathrm{n}} / R_{\mathrm{d}}$, and both exerted main effects (Table 5, $P<0.05$ ). Additionally, significant effects of temperature and light on the $R_{\mathrm{d}}$ were also observed, but there were no significant interactive effects between these two factors.

Table 5 Two-way analysis of variance for the effects of temperature and light intensity on the photosynthetic oxygen evolution

\begin{tabular}{lccc}
\hline \multicolumn{1}{c}{ Source } & df & F & Sig. \\
\hline$P_{\mathrm{n}}$ & & & \\
Temperature & 2 & 22.547 & 0.000 \\
Light & 2 & 173.965 & 0.000 \\
Temperature $\times$ Light & 4 & 9.885 & 0.000 \\
$R_{\mathrm{d}}$ & & & \\
Temperature & 2 & 4.171 & 0.032 \\
Light & 2 & 17.396 & 0.000 \\
Temperature $\times$ Light & 4 & 0.422 & 0.791 \\
$P_{\mathrm{n}} / R_{\mathrm{d}}$ & & & \\
Temperature & 2 & 27.495 & 0.000 \\
Light & 2 & 30.051 & 0.000 \\
Temperature $\times$ Light & 4 & 5.917 & 0.003 \\
\hline Notes: df, degrees of freedom; F, the value of the F statistic.
\end{tabular}

\section{Discussion}

Sargassum horneri distributes normally in intertidal and subtidal zones, and easily suffers from environmental stresses (temperature, light, salinity, desiccation) (Zhang et al., 2008). Among them, temperature and light are two main factors influencing the growth of $S$. horneri (Zeng and Wang, 2011). In the present study, we find that the suitable growth condition for $S$. horneri was the lowest temperature $\left(20^{\circ} \mathrm{C}\right)$ and highest light $(120 \mu \mathrm{mol}$ photons $\left.\mathrm{m}^{-2} \mathrm{~s}^{-1}\right)$, while the highest temperature $\left(30^{\circ} \mathrm{C}\right)$ seriously inhibited the growth, especially at lowest light $(30 \mu \mathrm{mol}$ photons $\mathrm{m}^{-2} \mathrm{~s}^{-1}$ ). As reported by Zhang et al. (2014), the suitable growth temperature for $S$. horneri was between 20 and $25^{\circ} \mathrm{C}$, while $30^{\circ} \mathrm{C}$ significantly inhibited the growth, and the optimal light was about $90 \mu$ molphotons $\mathrm{m}^{-2} \mathrm{~s}^{-1}$, which is consistent with our results. By affecting the main functional proteins, membranes, and other cellular components, temperature and light determine the growtho ef macroalgaes (Eggert 2012; (Su $/$ et al w 2014). At 
optimum temperature and light, the growth of macroalgae will be promoted; otherwise, it would be inhibited under supra- or sub-optimum conditions (Lideman et al., 2012; $\mathrm{Wu}$ et al., 2018). An elevated water temperature may be the main factor causing the decline of $S$. horneri beds (Zhang et al., 2008; Komatsu et al., 2014). The decreased transparency of water caused by re-suspension of amount sediments load in Nanji and Gouqi Islands enhanced the inhibition of high temperature on the growth of $S$. horneri (Sun et al., 2008; Bi and Wang, 2016). This is because the low light limited the photosynthesis, thus less energy was not strong enough to mitigate the negative effects of high temperature (Zeng et al., 2020).

Photosynthesis is easily affected by environmental stress. In our study, the photosynthetic oxygen evolution and chlorophyll fluorescence parameters were measured at the growth temperature and light in the culture under different temperatures and light intensities for $7 \mathrm{~d}$. These results show that the net photosynthetic rate $\left(P_{\mathrm{n}}\right)$ increased significantly with the light in regardless of temperature, while high temperature $\left(30^{\circ} \mathrm{C}\right)$ obviously inhibited the $P_{\mathrm{n}}$, and had a synergistic effect with light; low light $\left(30 \mu \mathrm{mol}\right.$ photons $\left.\mathrm{m}^{-2} \mathrm{~s}^{-1}\right)$ promoted the inhibitive effects of high temperature on the $P_{\mathrm{n}}$. High temperature affects the photosynthetic oxygen evolution by reducing the chloroplast electron transport, decreasing the photosynthetic pigments contents, and influencing the enzyme activity (Feller et al., 1998; Eggert, 2012). However, it was unusual that the photosynthetic pigments contents and the electron transport rates (ETR) at the end of induction curve were not significantly affected by temperature and light, indicating that the factors affecting $P_{\mathrm{n}}$ other than temperature and light. As shown in Fig.6b, the dark respiration rate $\left(R_{\mathrm{d}}\right)$ increased with increasing temperature, and higher light enhanced the effects of temperature on $R_{\mathrm{d}}$. In this case, the increased metabolic rate caused by high temperature consumed more energy and resulted in the reduction of growth (Wang and Wang, 2008). Moreover, high light could promote the accumulation of $\mathrm{Ru}$ bisco, while high temperature could reduce the Rubisco activity by inactivating the Rubisco activase (Koch et al., 2013; Beer et al., 2014). However, our results show that high temperature and high light led to a lower $P_{\mathrm{n}}$, indicating that the high temperature $\left(30^{\circ} \mathrm{C}\right)$ was the main limiting factor to $P_{\mathrm{n}}$. In addition, the $P_{\mathrm{n}} / R_{\mathrm{d}}$ increased with increasing light at 20 and $25^{\circ} \mathrm{C}$, while under high temperature $\left(30^{\circ} \mathrm{C}\right)$, no significant change was observed between light treatments. On the other hand, the $P_{\mathrm{n}} / R_{\mathrm{d}}$ decreased with the increasing temperature. These results indicate that the photosynthetic performance and accumulation of photosynthetic products were inhibited by high temperature and low light, and the high temperature $\left(30^{\circ} \mathrm{C}\right)$ was the primary factor (Li et al., 2000; Zhong et al., 2016).

Macroalgae have evolved in a series of protective mechanisms under environmental adversity (Mata et al., 2009), among which nonphotochemical quenching (NPQ) is an important protective mechanism. By NPQ, the ex(C) cess 4 -absorbed energy $_{\text {can }}$ be harmlessly dissipated quickly via thermal dissipation to avoid damage generated by light stress to plants. NPQ is often regarded as an indicator to a physiological stress (Niyogi, 2000), which has been proved in studies on algae (Gao et al., 2017, $2018 \mathrm{~b}$ ). In the present study, NPQ of higher light cultured algae was induced faster by increasing light under 20 and $25^{\circ} \mathrm{C}$. Especially at $30^{\circ} \mathrm{C}$, the effect of high light $(120$ $\mu \mathrm{mol}$ photons $\mathrm{m}^{-2} \mathrm{~s}^{-1}$ ) on NPQ was obvious, while the difference between 30 and $60 \mu \mathrm{mol}$ photons $\mathrm{m}^{-2} \mathrm{~s}^{-1}$ was not significant (Fig.5). The higher NPQ might be related to the accumulation of zeaxanthin, which is directly associated with NPQ in brown algae (Garcia-Mendoza et al., 2011; Pang, 2018). These results suggested that high light can provide more energy to synthesize zeaxanthin, thus to enhance the photo-protective ability of S. horneri. However, high temperature had antagonistic effect to high light thus weaker photo-protective ability. Besides, the maximal electron transport rate $\left(\mathrm{rETR}_{\max }\right)$ and half-saturation light intensity $\left(I_{\mathrm{k}}\right)$ were used to characterize the photo-acclimation ability (Behrenfeld et al., 2004; Ralph and Gademann, 2005; Serôdio et al., 2005; Pniewski et al., 2018). The higher values of $\mathrm{rETR}_{\max }$ and $I_{\mathrm{k}}$ indicated the higher light acclimation. As shown in Fig.4 and Table 4, the low temperature $\left(20^{\circ} \mathrm{C}\right)$ and high light $(120 \mu \mathrm{mol}$ photons $\mathrm{m}^{-2} \mathrm{~s}^{-1}$ ) treatments produced greater $I_{\mathrm{k}}$ and $\mathrm{rETR}_{\max }$, respectively. The reason might be that low temperature and high light cultured algae have enough energy for the synthesis of photosynthetic enzymes, electron chain components as well as the operation of photo-protective and energy-dissipating mechanisms (Hanelt and Figueroa, 2012), thus the thalli had higher light-saturation point, higher maximal photosynthetic rates at light saturation and increased effective photo-protection. As a result, under the low temperature and high light conditions, $S$. horneri displayed higher potential photosynthetic performance and could tolerate higher light, which had been proved by Pang (2018). On the contrary, under high temperature and low light conditions, $S$. horneri had weaker resistance to high light.

In conclusion, our study provided evidence that a high temperature could inhibit the growth, photosynthetic performance, and photo-protective ability of $S$. horneri, and low light further aggravated the adverse effects. Komatsu (2014) predicted that the southern limit S. horneri is gradually replaced by tropical species due to the impact of ocean warming. The annual sea surface temperatures (SST) in South China Sea is approaching to $28^{\circ} \mathrm{C}$ in recent years (Pang et al., 2018), and the ocean temperature will be elevating in the future (Zhu et al., 2019), thus the southern boundary may shift northward constantly and the decline of $S$. horneri beds in China may continue. Moreover, the negative effect would be magnified by low light. As been proved that the increasing of sediments load could restrict the adhesive ability and development of fertilized eggs, and re-suspension of the increment of sediments load decreased the transparency of seawater, lower the light intensity (Bi et al., 2014; Bi and Wang, 2016). Therefore, if the nearshore sediments load could not be reduced the phenomenon of decline of $S$. horneri 
will continue. As a consequence, the decline of S. horneri would be accelerated in the future.

\section{Acknowledgements}

This work was financially supported by the National Key Research and Development Program of China (No. 2016YFC1402106), the Technology Innovation Development Program of Yantai (No. 2020MSGY058), the National Natural Science Foundation of China (No. 31700 327), the Shandong Provincial Natural Science Foundation, China (No. ZR2019QD017), the Key R \& D Projects in Shandong Province (International Scientific and Technical Cooperation) (No. 2019GHZ026), and the Technology Innovation Development Program of Yantai (No. 2020MSGY068).

\section{References}

Bartsch, I., Wiencke, C., and Laepple, T., 2012. Global seaweed biogeography under a changing climate: The prospected effects of temperature. In: Seaweed Biology: Novel Insights into Ecophysiology, Ecology and Utilization. Wiencke, C., and Bischof, K., eds., Springer Berlin Heidelberg, Berlin, 383406.

Behrenfeld, M., Prasil, O., Babin, M., and Bruyant, F., 2004. In search of a physiological basis for covariations in light-limited and light-saturated photosynthesis. Journal of Phycology, 40: 4-25.

Bi, Y., and Wang, W., 2016. effects of wind wave on distribution pattern of Sargassum Horneri around Gouqi Island. Chinese Journal of Ecology, 35: 1595-1600 (in Chinese with English abstract).

Bi, Y., Zhang, S., and Wu, Z., 2013. Seasonal variations of Sargassum Horneri distribution around Gouqi Island of east China. Chinese Journal of Ecology, 32: 1255-1259 (in Chinese with English abstract).

Bi, Y., Zhang, S., Wang, W., and Wu, Z., 2014. Vertical distribution pattern of Sargassum Horneri and its relationship with environmental factors around Gouqi Island. Acta Ecologica Sinica, 34: 4931-4937 (in Chinese with English abstract).

Chen, Y., Chen, S., Ma, C., Yu, S. Y., Yang, L., Zhang, Z., and Yao, M., 2014. Palynological evidence of natural and anthropogenic impacts on aquatic environmental changes over the last 150 years in Dongping Lake, North China. Quaternary International, 349: 2-9.

Choi, H., Lee, K., Yoo, H., Kang, P., Kim, Y., and Nam, K., 2008. Physiological differences in the growth of Sargassum horneri between the germling and adult stages. Journal of Applied Phycology, 20: 729-735.

Deregibus, D., Quartino, M., Campana, G. L., Momo, F., Wiencke, C., and Zacher, K., 2016. Photosynthetic light requirements and vertical distribution of macroalgae in newly ice-free areas in Potter Cove, South Shetland Islands, Antarctica. Polar Biology, 39: 153-166.

Diaz-Pulido, G., Gouezo, M., Tilbrook, B., Dove, S., and Anthony, K. R. N., 2011. High $\mathrm{CO}_{2}$ enhances the competitive strength of seaweeds over corals. Ecology Letters, 14: 156-162.

Eggert, A., 2012. Seaweed responses to temperature. In: Seaweed Biology: Novel Insights into Ecophysiology, Ecology and Utilization. Wiencke, C., and Bischof, K., eds., Springer (C) 1994-2021 China Academic Journal Electronic PublishinNoriheast. Asia rinders A2s escendrio betglobal/warming nand
Berlin Heidelberg, Berlin, 47-66.

Eriksson, B., and Johansson, G., 2005. Effects of sedimentation on macroalgae: Species-specific responses are related to reproductive traits. Oecologia, 143: 438-448.

Feller, U., Crafts-Brandner, S. J., and Salvucci, M. E., 1998. Moderately high temperatures inhibit ribulose-1,5-bisphospate carboxylase/oxygenase (Rubisco) activase-mediated activation of Rubisco. Plant Physiology, 116: 539-546.

Gao, G., Clare, A. S., Chatzidimitriou, E., Rose, C., and Caldwell, G., 2018a. Effects of ocean warming and acidification, combined with nutrient enrichment, on chemical composition and functional properties of Ulva rigida. Food Chemistry, 258: 71-78.

Gao, G., Liu, Y., Li, X., Feng, Z., Xu, Z., Wu, H., and Xu, J., 2017. Expected $\mathrm{CO}_{2}$-induced ocean acidification modulates copper toxicity in the green tide alga Ulva prolifera. Environmental and Experimental Botany, 135: 63-72.

Gao, G., Xu, Z., Shi, Q., and Wu, H., 2018b. Increased $\mathrm{CO}_{2}$ exacerbates the stress of ultraviolet radiation on photosystem II function in the diatom Thalassiosira weissflogii. Environmental and Experimental Botany, 156: 96-105.

Garcia-Mendoza, E., Ocampo-Alvarez, H., and Govindjee, S., 2011. Photoprotection in the brown alga Macrocystis Pyrifera: Evolutionary implications. Journal of Photochemistry and Photobiology B: Biology, 104: 377-385.

Gutu, A., Nesbit, A., Alverson, A., Palmer, J., and Kehoe, D., 2013. Unique role for translation initiation factor 3 in the light color regulation of photosynthetic gene expression. Proceedings of the National Academy of Sciences of the United States of America, 110 (40): 16253-16258.

Hanelt, D., and Figueroa, F. L., 2012. Physiological and photomorphogenic effects of light on marine macrophytes. In: Seaweed Biology: Novel Insights into Ecophysiology, Ecology and Utilization. Wiencke, C., and Bischof, K., eds., Springer Berlin Heidelberg, Berlin, 3-23.

Hanelt, D., Wiencke, C., and Bischof, K., 2003. Photosynthesis in marine macroalgae. In: Photosynthesis in Algae. Larkum, A. W. D., et al., eds., Springer Netherlands, Dordrecht, 413435.

Harley, C., Anderson, K., Demes, K., Jorve, J., Kordas, R., Coyle, T., and Graham, M., 2012. Effects of climate change 1064-1078.

Hoegh-Guldberg, O., and Bruno, J., 2010. The impact of climate change on the world's marine ecosystems. Science, 328 (5985): 1523-1528.

Ji, Y., Xu, Z., Zou, D., and Gao, K., 2016. Ecophysiological responses of marine macroalgae to climate change factors. Journal of Applied Phycology, 28: 2953-2967.

Jueterbock, A., Tyberghein, L., Verbruggen, H., Coyer, J A., Olsen, J. L., and Hoarau, G., 2013. Climate change impact on seaweed meadow distribution in the North Atlantic rocky intertidal. Ecology and Evolution, 3: 1356-1373.

Khan, A., Levac, E., Guelphen, L., Pohle, G., and Chmura, G., 2018. The effect of global climate change on the future distribution of economically important macroalgae (seaweeds) in the Northwest Atlantic. Facets, 3: 275-286.

Koch, M., Bowes, G., Ross, C., and Zhang, X. H., 2013. Climate change and ocean acidification effects on seagrass and marine macroalgae. Global Change Biology, 19: 103-132.

Komatsu, T., Fukuda, M., Mikami, A., Mizuno, S., Kantachumpoo, A., Tanoue, H., and Kawamiya, M., 2014. Possible change in distribution of seaweed, Sargassum horneri, in on global seaweed communities. Journal of Phycology, 48: 
consequent effect on some fish. Marine Pollution Bulletin, 85: 317-324.

Lideman, G. N., Noro, T., and Terada, R., 2012. Effect of temperature and light on the photosynthetic performance of two edible seaweeds: Meristotheca coacta Okamura and Meristotheca papulosa J. Agardh (Solieriaceae, Rhodophyta). Aquaculture Science, 60: 377-388.

Li, K., Pan, Y., Wu, J., and Xiao, X., 2017. Effect of LED lightings on growth of Sargassum horneri under different photoperiods. Acta Agriculturae Zhejiangensis, 29 (4): 631-636 (in Chinese with English abstract).

Liu, L., Zou, D., Jiang, H., Chen, B., and Zeng, X., 2017. Effects of increased $\mathrm{CO}_{2}$ and temperature on the growth and photosynthesis in the marine macroalga Gracilaria lemaneiformis from the coastal waters of South China. Journal of Applied Phycology, 30: 1271-1280.

Li, X. P., Björkman, O., Shih, C., Grossman, A. R., Rosenquist, M., Jansson, S., and Niyogi, K. K., 2000. A pigment-binding protein essential for regulation of photosynthetic light harvesting. Nature, 403 (6768): 391-395.

Ma, A. C., Chen, Z., Wang, T., Song, N., Yan, Q., Fang, Y. C., Guan, H. S., and Liu, H., 2014. Isolation of the molecular species of monogalactosyldiacylglycerols from brown edible seaweed Sargassum horneri and their inhibitory effects on triglyceride accumulation in 3T3-L1 adipocytes. Journal of Agricultural and Food Chemistry, 62 (46): 11157-11162.

Mata, Y. N., Blázquez, M. L., Ballester, A., González, F., and Muñoz, J. A., 2009. Biosorption of cadmium, lead and copper with calcium alginate xerogels and immobilized Fucus vesiculosus. Journal of Hazardous Materials, 163: 555-562.

Müller, R., Laepple, T., Bartsch, I., and Wiencke, C., 2009. Impact of oceanic warming on the distribution of seaweeds in polar and cold-temperate waters. Botanica Marina, 52: 617638.

Niyogi, K. K., 2000. Safety valves for photosynthesis. Current Opinion in Plant Biology, 3: 455-460.

Olabarria, C., Arenas, F., Viejo, R., Gestoso, I., Vaz-Pinto, F., Incera, M., Rubal, M., Cacabelos, E., Veiga, P., and Sobrino, C., 2013. Response of macroalgal assemblages from rockpools to climate change: Effects of persistent increase in temperature and $\mathrm{CO}_{2}$. Oikos, 122 (7): 1065-1079.

Pan, J., and Guo, B. L., 2016. Effects of light intensity on the growth, photosynthetic characteristics, and flavonoid content of Epimedium pseudowushanense B.L.Guo. Molecules, 21 (11): 1475

Pang, Y. L., 2018. Ecological adaptability and genetic diversity of floating Sargassum horneri in the North Yellow Sea. PhD thesis. University of Chinese Academy of Sciences.

Pang, Y., Tian Y., Fu, C., Wang, B., Li, J., Ren, Y., and Wan, R. 2018. Variability of coastal cephalopods in overexploited China Seas under climate change with implications on fisheries management. Fisheries Research, 208: 22-33.

Parsons, T. R., and Strickland, J. D., 1963. Discussion of spectrophotometric determination of marine plant pigments with revised equations for ascertaining chlorophylls. Journal of Marine Research, 21: 155-163.

Platt, T., Gallegos, C., and Harrison, W., 1980. Photoinhibition of photosynthesis in natural assemblages of marine phytoplankton. Journal of Marine Research, 38: 687-701.

Pniewski, F., Richard, P., Latała, A., and Blanchard, G., 2018. Long- and short-term photoacclimation in epipsammon from non-tidal coastal shallows compared to epipelon from intertidal mudflat. Journal of Sea Research, 136: 1-9.
Survival in low light: Photosynthesis and growth of a red alga in relation to measured in situ irradiance. Journal of Phycology, 49: 867-879.

Porra, R. J., 2002. The chequered history of the development and use of simultaneous equations for the accurate determination of chlorophylls $a$ and $b$. Photosynthesis Research, 73: 149-156.

Quartino, M. A. L., Deregibus, D., Campana, G. L., Latorre, G. E. J., and Momo, F. R., 2013. Evidence of macroalgal colonization on newly ice-free areas following glacial retreat in potter cove (South Shetland Islands), Antarctica. PLoS One, 8: e58223.

Rahman, M., Noor, N., Saad, S., and Yunus, K., 2015. Coastal water quality of Tioman Island: Effects of human activity and the distance from shoreline. Desalination and Water Treatment, 57: 1-5.

Ralph, P. J., and Gademann, R., 2005. Rapid light curves: A powerful tool to assess photosynthetic activity. Aquatic Botany, 82 (3): 222-237.

Sanjeewa, A., Fernando, S., Kim, E. A., Ahn, G., Jee, Y., and Jeon, Y. J., 2017. Anti-inflammatory activity of a sulfated polysaccharide isolated from an enzymatic digest of brown seaweed Sargassum horneri in RAW 264.7 cells. Nutrition Research and Practice, 11 (1): 3-10.

Serôdio, J., Vieira, S., Cruz, S., and Barroso, F., 2005. Shortterm variability in the photosynthetic activity of microphytobenthos as detected by measuring rapid light curves using variable fluorescence. Marine Biology, 146: 903-914.

Smetacek, V., and Zingone, A., 2013. Green and golden seaweed tides on the rise. Nature, 504: 84-88.

Su, N., Wu, Q., Shen, Z., Xia, K., and Cui, J., 2014. Effects of light quality on the chloroplastic ultrastructure and photosynthetic characteristics of cucumber seedlings. Plant Growth Regulation, 73: 227-235.

Sun, J. Z., Chen, W. D., Zhuang, D. G., Zheng, H. Y., Lin, L., and Pang, S. J., 2008. In situ ecological studies of the subtidal brown alga Sargasssum horneri at Nanji Island of China. South China Fisheries Science, 4: 58-63.

Beer, S., Björk, M., and Beardall, J., 2014. Photosynthesis in the Marine Environment. 1st edition. 157-169.

Wang, H., Gu, M., Cui, J., Shi, K., Zhou, Y., and Yu, J., 2009. Effects of light quality on $\mathrm{CO}_{2}$ assimilation, chlorophyllfluorescence quenching expression of Calvin cycle genes and carbohydrate accumulation in Cucumis sativus. Journal of Photochemistry and Photobiology. B, Biology, 96: 30-37.

Wang, M. J., and Wang, W. X., 2008. Temperature-dependent sensitivity of a marine diatom to cadmium stress explained by subcelluar distribution and thiol synthesis. Environmental Science \& Technology, 42: 8603-8608.

Wernberg, T., Bennett, S., Babcock, R., De Bettignies, T., Cure, K., Depczynski, M., Dufois, F., Fromont, J., Fulton, C., Hovey, R., Harvey, E., Holmes, T., Kendrick, G., Radford, B., Santana-Garcon, J., Saunders, B., Smale, D., Thomsen, M., Tuckett, C., and Wilson, S., 2016. Climate-driven regime shift of a temperate marine ecosystem. Science, 353: 169-172.

Wernberg, T., Russell, B. D., Thomsen, M. S., Frederico, C., Gurgel, D., Corey, J. A., Poloczanska, E. S., and Connell, S. D., 2011. Seaweed communities in retreat from ocean warming. Current Biology, 21: 1828-1832.

Wu, H., Feng, J., Li, X., Zhao, C., Liu, Y., Yu, J., and Xu, J., 2019. Effects of increased $\mathrm{CO}_{2}$ and temperature on the physiological characteristics of the golden tide blooming macroalgae Sargassum horneri in the Yellow Sea, China. Marine Pollution Bulletin, 146: 639-644. 
Wu, H. L., Gao, G., Zhong, Z. H., Li, X. S., and Xu, J. T., 2018. Physiological acclimation of the green tidal alga Ulva prolifera to a fast changing environment. Marine Environmental Research, 137: 1-7.

$\mathrm{Xu}, \mathrm{Y}$., and Lin, J., 2008. Effect of temperature, salinity, and light intensity on the growth of the green macroalga, Chaetomorpha linum. Journal of the World Aquaculture Society, 39: $847-851$.

Xu, Z., Gao G., Xu, J., and Wu, H., 2016. Physiological response of a golden tide alga (Sargassum muticum) to the interaction of ocean acidification and phosphorus enrichment. Biogeosciences, 14: 671-681.

Yang, X. Q., Zhang, Q. S., Zhang, D., Feng, J. X., Zhao, W., Liu, Z., and Tan, Y., 2018. Interaction of high seawater temperature and light intensity on photosynthetic electron transport of eelgrass (Zostera marina L.). Plant Physiology and Biochemistry, 132: 453-464.

Yoshida, T., 1983. Japanese species of Sargassum subgenus Bactrophycus (Phaeophyta, Fucales). Journal of the Faculty of Science, Hokkaido University. Series 5, Botany, 13: 99246.

Zeng, C. K., and Lu, B. J., 2000. Marine Algae Flora of China. (3rd edition). Science Press, Beijing, 1-21 (in Chinese).

Zeng, J., and Wang, W. X., 2011. Temperature and irradiance influences on cadmium and zinc uptake and toxicity in a freshwater cyanobacterium, Microcystis aeruginosa. Journal of Hazardous Materials, 190: 922-929.

Zeng, X. P., Jin, P., Jiang, Y. Y., Yang, H. M., Zhong, J. H., Li- ang, Z., Guo, Y. Y., Li, P. Y., Huang, Q. T., Pan, J. M., Lu, H., Wei, Y. Y., Zou, D. H., and Xia, J. R., 2020. Light alters the responses of two marine diatoms to increased warming. $\mathrm{Ma}$ rine Environmental Research, 154: 104871.

Zhang, P., Wang, T., Xie, Q., Zhang, H., Yan, X., and Chen, M., 2014. Effects of environment factors on growth of Sargassum horneri seedlings under indoor conditions. Journal of Shanghai Ocean University, 23: 200-207.

Zhang, S. Y., Wang, L., and Wang, W. D., 2008. Algal communities at Gouqi Island in the Zhoushan archipelago, China. Journal of Applied Phycology, 20: 853-861.

Zhang, S., Bi, Y., and Wu, Z., 2013. Spatial distribution pattern of Sargassum horneri around Gouqi Island, Shengsi, China. Journal of Fisheries of China, 37: 884 (In Chinese).

Zhao, D., Zheng, L., Qi, L., Wang, S., Guan, L., Xia, Y., and Cai, J., 2016. Structural features and potent antidepressant effects of total sterols and $\beta$-sitosterol extracted from Sargassum horneri. Marine Drugs, 14 (7): 123.

Zhong, Z. H., Wang, W. J., Sun, X. T., Liu, F. L., Liang, Z. R., Wang, F. J., and Chen, W. Z., 2016. Developmental and physicological properties of Pyropia dentata (Bangiales, Rhodophyta) conchocelis in culture. Journal of Applied Phycology, 28: 3435-3445.

Zhu, X. X., Wang, Y. Y., Hou, X. Y., Kong, Q. D., Sun, Y. F., Wang, J., Huang, Y., and Yang, Z., 2019. High temperature promotes the inhibition effect of $\mathrm{Zn}^{2+}$ on inducible defense of Scenedesmus obliquus. Chemosphere, 216: 203-212.

(Edited by Ji Dechun) 